\title{
The Numa Numa Dance e Gangnam Style: vídeos musicais no Youtube em múltiplas mediações
}

\author{
Simone Pereira de Sá
}

Resumo: O trabalho aborda os vídeos The Numa Numa Dance - vídeo amador cover precursor dos virais musicais, veiculado em 2004 por Gary Brolsma; e Gangnam Style, do Dj Psy videoclipe oficial da canção do pop coreano e o vídeo mais visto da história do Youtube; buscando discutir os processos de mediação que envolvem a circulação desses vídeos em perspectiva comparada. A premissa central é a de que The Numa Numa Dance é precursor de uma categoria de vídeos musicais que nos ajuda a entender o sucesso de Gangnam Style posteriormente; e que ambos se inscrevem na mesma rede sociotécnica que articula amadores e profissionais, indústria cultural e usuários comuns e que, mapeadas, nos revelam aspectos importantes da cultura musical contemporânea circulando através das redes digitais.

Palavras-chave: teoria ator-rede; Youtube; videoclipes.

Abstract: The Numa Numa Dance and Gangnam Style: musical videos on youtube in multiple mediation - This paper examines the videos The Numa Numa Dance - a 2004 amateur video uploaded by Gary Brolsma and taken as a precursor of viral musical videoclips, and Gangnam Style, by Dj Psy - the official music video of a k-pop song and the most frequently watched videoclip in the history of YouTube, and discusses the mediation process whereby these videos circulate on YouTube from a comparative perspective. The core premise is that The Numa Numa Dance is the precursor of a category of music videos that later help us understand the success of Gangnam Style, and that they both fall within the same sociotechnical network that links amateur and professional people, cultural industry and common users. Once they are mapped, these networks reveal important aspects of contemporary musical culture circulating through digital media.

Keywords: actor-network theory; YouTube; musical videoclips. 


\section{Introdução}

Em dezembro de 2004, um pequeno artefato cultural tornou-se um vídeo viral de proporções inacreditáveis para a banalidade da cena: um rapaz dançava diante da sua webcam, acompanhando com os lábios uma canção desconhecida, que ele intitulou The Numa Numa dance. ${ }^{1}$ OYoutube ainda não existia; e o vídeo foi primeiramente postado no site Newgrounds.com. Transferido para o Youtube em 2006, manteve-se por alguns anos no topo do ranking de vídeos mais vistos da plataforma. ${ }^{2}$

De ilustre desconhecido, Gary Brolsma, o americano de New Jersey que protagonizou o acontecimento, tornar-se-ia a partir daquele episódio uma celebridade da cultura digital. E a canção Dragostea Din Tei, da banda romena O-Zone, tornou-se um hit pop regravado em vários idiomas. ${ }^{3}$ Paródias, respostas e novas iniciativas do próprio Brolsma, que superou o susto assumindo a persona de The Numa Numa guy e buscando se profissionalizar a partir da fama, marcam a trajetória desse vídeo e seu autor. ${ }^{4}$

Quase uma década depois, um vídeo explodiu no Youtube em 2012: Gangnam Style, do DJ Psy. ${ }^{5}$ Novamente protagonizado por um desconhecido - pelo menos aos olhos ocidentais - e cantado em coreano, o videoclipe atingiu 805 milhões de visualizações no mês de seu lançamento; e permanece, dois anos depois, como o número 1 da história do Youtube, com a marca recorde de dois bilhões de acessos. Ao contrário do vídeo amador de Brolsma, Gangnam Style é um videoclipe oficial e insere-se dentro das estratégias de internacionalização da indústria cultural sul-coreana, o k-pop.

Separados por quase dez anos, The Numa Numa Dance e Gangnam Style cobrem a temporalidade em que o Youtube se consolidou como plataforma para distribuição de vídeos. ${ }^{6}$ E apesar da aparente distância, minha aposta é a de que The Numa Numa Dance é precursor de uma categoria de vídeos musicais que nos ajuda a entender o sucesso de Gangnam Style posteriormente; e que ambos se inscrevem na mesma rede sociotécnica que articula amadores e profissionais, indústria cultural e usuários comuns e que, rastreadas, revelam-nos aspectos importantes da cultura musical atual e suas práticas de circulação nas redes digitais.

Dois elementos desse episódio justificam meu interesse por esses vídeos. Primeiramente, o protagonismo do Youtube na mediação do processo, uma vez que o número recorde de acessos se tornou o cartão de visitas que abriu as portas de outras

1 Disponível em: <http://www.youtube.com/watch?v=KmtzQCSh6xk>. Acesso em: 16 jun. 2014

2 Segundo a BBC, em 2006, o vídeo ocupava o segundo entre os virais mais vistos da história do Youtube, com 700 milhões de views e abaixo somente do vídeo Star War Kid - uma paródia da série Stars Wars. Disponível em: <http://news.bbc.co.uk/2/hi/entertainment/6187554.stm>.Acesso em: 16 jun. 2014

3 Inclusive em português, pelo cantor Latino, como Festa no apê.

4 Em 2007, o canal VH1 elegeu por votação as maiores "celebridades da internet" e Brolsma ficou em primeiro lugar. Disponível em: <http://www.youtube.com/watch?v=W9m9UFhEARg $>$. Para uma análise da trajetória desse vídeo, ver também o site Know your meme. Disponível em: <http://knowyourmeme.com/memes/numanuma>. Acesso em: 16 jun. 2014

5 Disponível em: <http://www.youtube.com/watch?v=9bZkp7q19f0>. Acesso em: 16 jun. 2014

6 Criada, em 2005, por Chad Hurley, Steve Chen e Jawed Karim, para ser um canal de veiculação de vídeos domésticos, a plataforma foi comprada, em 2006, pelo Google por cerca de dois milhões de dólares. 
mídias e deu visibilidade a Gary Brolsma e DJ Psy. Em segundo, a rede de mediações que enreda esses videoclipes no Youtube.

Dessa maneira, parto da análise desses vídeos a fim de explorar aspectos dos processos de mediação do Youtube tanto quanto suas práticas e valores, chamadas por Burguess e Green (2009) de youtubidade.

Nesta reflexão, meu trabalho diverge de algumas análises que se apoiam numa divisão estrita entre vídeos amadores e profissionais, seja para demonizar a categoria de amador, na linha de argumentação sobre a cultura participativa popularizada por Keen (2009); seja para valorizar a lógica bottom-up e romantizar a participação dos usuários comuns como pioneira e autêntica; enquanto que a entrada dos pesos pesados da indústria do entretenimento na plataforma caracterizaria um segundo momento, que inverte a lógica anterior de baixo para cima e coloca em risco o potencial democrático da cultura participativa.

Contrário a essa premissa, sustento, em diálogo com Burguess e Green (2009) e Muller (2009), que a rede de mediadores que transformou o Youtube num sistema cultural é ampla, complexa e heterogênea, indo além da dicotomia entre usuários comuns (amadores) versus profissionais. E que o conjunto de práticas, valores e sensibilidades construído pela cultura amadora em torno de vídeos tais como The Numa Numa dance é, em parte, responsável pelo (bom) acolhimento de uma audiência global a Gangnam Style.

Este trabalho dialoga, portanto, por um lado, com os trabalhos que abordam a cultura participativa como mola mestre da indústria do entretenimento atual, tais como o já célebre Cultura da Convergência (JENKINS, 2008) ou artigos sobre a cultura do spoof (FELINTO, 2008); por outro, com os trabalhos que buscam entender as relações entre som e imagem no ambiente da cultura digital (SNICKARS; VONDERAU, 2009; STRANGELOVE, 2010; VERNALLIS, 2013; HOLZBACH; NERCOLINI, 2009; SOARES, 2009; CONTER, 2013; ZILLER, 2012), discutindo especificamente, neste caso, algumas inflexões da cultura pop no ambiente do Youtube.

Por fim, ao mencionar essa proposta, cabe adiantar a resposta a uma possível crítica que aposta no hibridismo do Youtube e na sua convergência (JENKINS, 2008) com outras redes, uma vez que vídeos do Youtube podem ser incorporados em todos os outros meios, como suas características mais destacadas. Além disso, como repositório de arquivos, o Youtube acolhe vídeos de origens muitíssimo diversificadas e não somente videoclipes musicais.

Embora concorde com a perspectiva acima delineada, acredito que ela possa ser conjugada com a discussão mais pontual e focada na cultura da música neste ambiente, uma vez que entre os vídeos mais vistos do Youtube, a proeminência dos videoclipes musicais é indiscutível; ao mesmo tempo que o se trata também da plataforma musical mais utilizada para música hoje. ${ }^{7}$

7 A título de exemplo, os dados mostram que entre os trinta vídeos mais vistos da história do Youtube, 29 são videoclipes musicais. Disponível em: <http://top10mais.org/top-10-videos-mais-vistos-youtube/\#prettyPhoto>. Acesso em: 16 jun. 2014 
Assim, este trabalho parte da premissa de que a plataforma, embora se comunique e remedeie outros meios - tais como a televisão e o rádio - e possa ser pensada como um nó numa rede sociotécnica maior, desafia-nos a entendê-la como tecnologia e forma cultural (WILLIAMS, 1990), uma vez que ela ocupa um papel central como mediadora $\left(\right.$ LATOUR, 2005) ${ }^{8}$ da experiência musical nas redes digitais. Busco, portanto, especular sobre algumas das capacidades expressivas desse ambiente, definidas a partir das práticas de usuários comuns; e que parecem estar produzindo algumas inflexões na música pop.

Para tanto, parti da circulação dos vídeos e busquei os comentários dos usuários, filtrados cronologicamente a partir do recorte dos dois últimos anos, a fim de identificar e discutir, em caráter exploratório, algumas mediações do processo.

\section{Marcas de youtubidade em The Numa Numa Dance}

No caso da música, a muito grosso modo, podemos classificar o conteúdo musical postado no Youtube em três amplos conjuntos. Primeiramente, encontramos o conteúdo produzido pela indústria da música ao longo dos séculos XX e XXI: videoclipes, programas musicais de televisão; fragmentos de shows, musicais e outros produtos. Esse conteúdo, por sua vez, pode ser postado na plataforma tanto pelas grandes corporações de mídias, em seus canais, no contexto de um plano estratégico que visa a ampliar a visibilidade e a audiência de seus produtos e artistas tanto quanto o fortalecimento da própria marca; ${ }^{9}$ como também pode ser postado por usuários comuns, a partir de arquivos pessoais oriundos de garimpagem na televisão, transposição de conteúdo raro de videocassetes antigos etc. Nesse mesmo grupo se incluem ainda os produtos audiovisuais autorais independentes, postados por usuários relativamente profissionais, que buscam a expressão e a visibilidade nas redes sociais.

Em segundo lugar, temos o conteúdo produzido por usuários comuns sobre artistas profissionais, na forma de gravação de shows e apresentações gravadas e editadas pelos próprios usuários. Eventualmente sem a mesma qualidade técnica do material disponibilizado pelas grandes corporações, esse conteúdo é muito valorizado como testemunho e registro memorialístico de shows e eventos, sobretudo quando o registro oficial não foi disponibilizado para os fãs.

Finalmente, a terceira categoria é a dos vídeos amadores que dialogam criativamente com a cultura da música gravada. Nessa categoria entram as reinterpretações e apropriações de canções - remakes, covers, mashups e outras formas intertextuais - compostas a partir de imagem e som preexistentes; na qual se insere nosso primeiro vídeo, The Numa Numa dance.

8 Buscando sintetizar uma longa discussão, podemos afirmar, com Latour (2005), que um mediador se distingue de um intermediário por alterar, desviar ou produzir diferença numa rede sociotécnica. Esse aspecto da discussão é fundamental para meu argumento, uma vez que anula a hierarquia entre sujeitos e objetos e possibilita o reconhecimento dos artefatos técnicos como coatores em qualquer rede estabelecida com humanos.

9 Tal como o VEVO, site criado, em 2009, a partir de consórcio que envolve as empresas Sony, Universal, Abu Dhabi Media e grupo Disney, além de suas subsidiárias, visando disponibilizar conteúdo oficial e combater a "pirataria" virtual; e que possui forte presença no Youtube, através de seu grupo de canais. 

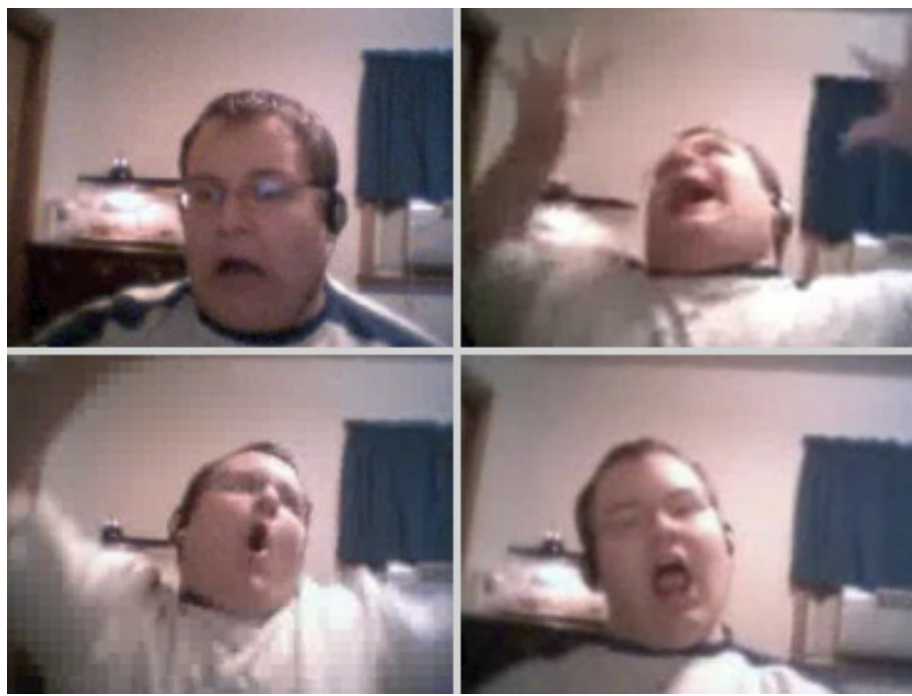

Fig.1. Gary Broslma em cena do videoclipe The Numa Numa Dance.

Trata-se de um vídeo curto, de menos de dois minutos, gravado por uma webcam, cuja locação sugere o espaço doméstico do próprio quarto de Brolsma, com objetos ao fundo. Contudo, o foco da câmera é no próprio rosto do rapaz e a parte superior de seu tronco. E o que vemos é o jovem de frente para a webcam, sentado, acompanhando com os lábios - técnica conhecida como lip-synching - uma canção desconhecida e fazendo movimentos com os olhos, boca, cabeça e mãos, dançando ritmadas acima do tronco, em sincronia com o ritmo, sem se levantar da cadeira. Espontaneidade, sinceridade, humor, simplicidade e diversão 'presenteísta' e efêmera - como se a câmera o tivesse flagrado - são os elementos que sobressaem na filmagem caseira, granulada e sem edição mais elaborada.

Porém, ao mesmo tempo que o vídeo evoca sinceridade e espontaneidade, fica claro que Gary está ciente da mediação da webcam e sua performance foi ensaiada para ser representada na frente da câmera. Nesse sentido, acompanho o argumento de Peter e Seier (2009, p. 189), que em sua análise de vídeos de dança caseiros entendem essa categoria como uma das formas de "automediação" (em diálogo com DUNNE; MOSER, 2008) - expressão do self mediada por tecnologias.

Assim, como toda performance, ela é ao mesmo tempo um processo comunicativo ancorado na corporeidade e uma experiência de sociabilidade, uma vez que supõe regras e convenções negociadas a partir dos gêneros musicais e das comunidades de gosto. E só funciona para uma audiência que compreende os gestos encenados como fazendo sentido, a partir da sua própria experiência performática. (PEREIRA DE SÁ; HOLZBACH, 2010).

Prosseguindo no argumento, Peters e Seier defendem que a mediação do computador deve ser pensada não só em relação à gravação, edição e upload do vídeo; mas também na forma como - através do Youtube - constitui-se um arquivo de poses e gestos, 
produzido coletivamente na forma de reconhecimentos, repetições e imitações de performances da música pop.

[...] Experiências subjetivas estão inseparavelmente fundidas com a recepção midiática. Os horizontes de conhecimento e experiência do pop incluem tanto suar na discoteca quanto assistir MTV. Tecnologias do self e tecnologias das mídias são mutuamente determinantes." (PETERS; SEIER, 2009, p. 197-198, tradução da autora).

A dupla de autores toma por objeto os vídeos de dança caseiros (home dance videos), onde pessoas comuns dançam ao som de músicas pop. Contudo, dando mais um passo, pretendo destacar a forma como esse clipe não só é o precursor da estirpe de vídeos amadores de danças caseiras; mas sobretudo como, depois de se tornar um viral, ele também se inscreve dentro do horizonte de experiências e conhecimento da música pop, mencionado pelos autores, tornando-se uma referência musical oriunda do Youtube.

Assim, se a noção de performance, entendida como a mediação do corpo, é central para a compreensão da experiência de fruição estética da música (FRITH, 1998, p. 21); proponho chamar de gesto performático o gesto ou conjunto gestual que define de forma sintética uma performance, transformando-a numa marca identitária da canção ou do artista. Dessa maneira, o gesto performático pode ser pensado como o gesto icônico do intérprete de uma canção, que cria imediato vínculo e afeto. E, se ele pode ser observado ao longo da história da música $p o p^{10}$ e constitui-se como um elemento central da comunicação com a audiência, no Youtube, ele ganha centralidade, uma vez que é a partir desse gesto que reconhecemos a citação do vídeo a cada nova apropriação.

Com base nessas discussões, meu argumento é o de que o cenário despojado; a coreografia que coloca o corpo em evidência, olhando para a câmera e destacando os gestos performáticos que a identificam imediatamente; e elementos tais como humor, espontaneidade, improviso e nonsense se tornaram marcas estéticas importantes para circulação de vídeos musicais no Youtube; constituindo uma matriz associada ao amadorismo e valorizada como "vídeos de youtube" pelos usuários.

\section{A "performance de gosto" dos usuários via comentários}

O conjunto de comentários recentes sobre o vídeo de Brolsma ${ }^{11}$ permite a sua organização em três subconjuntos.

10 Como, por exemplo, o passo de dança moonwalk imortalizado por Michael Jackson. Nesse sentido, enquanto a performance é uma atitude corporal mais "abrangente", que pode ocorrer de maneira relativamente discreta, até mesmo com o corpo em aparente imobilidade, o gesto performático é sempre eloquente, visível e de reconhecimento imediato.

11 O vídeo foi postado pelo usuário @Thegeeker, em 11 de dezembro de 2006. Não se trata, portanto, do vídeo original, mas um dos "espelhos" (versões idênticas do vídeo) que circulam no Youtube. No momento da consulta, em 31 de janeiro de 2014, ele tem 20.722.294 views. Os comentários selecionados são os mais recentes, realizados entre novembro de 2013 e janeiro de 2014. Disponível em: <http://www.youtube.com/ watch?v=KmtzQCSh6xk>. Acesso em: 3 fev. 2014. 
O primeiro, que enfatiza a performance e os aspectos "corporais" do vídeo, tais como: "I love that fatman" (@NikosAgg); "This is why I started my Youtube channel" (@DracoChu); "So sexy" (@Sarah); "That eyebrow" (@BriPod) são alguns dos comentários simples, sintéticos e diretos.

Um segundo subconjunto é formado por comentários de usuários que postam a partir de suas memórias afetivas e de como o vídeo se tornou uma referência: "Still good meme" (@Lag Master); "So old and classic" (@Davis Unknown); "You were popular when I was in middle school. Even my 7th grade science teacher talked about you...for some reason." (@xHAMxNelson).

Em 2007, o canal VH1 realizou uma votação para eleger as maiores "celebridades da internet" e Gary Brolsma foi agraciado com o primeiro lugar. ${ }^{12}$ Nos comentários que acompanham o vídeo produzido pelo canal televisivo, também se destacam posts relevantes para o debate: "I Dance And Sing Along To This Awesome Epic Video", comenta @kanerules7 (fev. 2012); enquanto @ rachiti replica:

wow, I can't believe it's been that many years already. Nowadays everybody shoots videos of every little thing but "back in the day", uploading a webcam-shot video wasn't common at all. Did youtube even exist back then? I know I sure hadn't heard of it. (@rachiti, fev. 2012)

Um terceiro vídeo, que retrata os personagens de animação da série americana South Park parodiando os vídeos mais vistos da internet - e que inclui o The Numa Numa dance - recebeu comentários recentes, relativos ao mês de fevereiro de 2014, os quais também merecem destaque, ${ }^{13}$ por apontarem para o terceiro subconjunto de comentários. Este constituído por posts que acionam a disputa simbólica entre usuários sobre "quem pode opinar", com base no quanto eles conhecem da própria história dos vídeos de Youtube: "Nobody remembers these guys now", escreve @ midnightswordsclan.

E seguem-se as réplicas: "i remember them all" (@CedricC98); "if you don't remember these guys, your just a poser whom only follows fads" (@nsdfnsdf); "How could you NOT remember these guys... These were the very first milion hits on the youtube. They are legends. Today to watch a video, and the next day you can't remember what it was"(@ StigAndresen); "they will always be here...in my HEART!" (@FedericoSilano).

Esse conjunto de comentários foi realizado nos últimos dois anos, entre 2012 e 2014. Nesse período, como sabemos, muitos outros virais, inclusive musicais, chamaram a atenção e foram compartilhados. Mas o sentimento recorrente de que The Numa Numa Dance é "lendário", "épico", "clássico" ajuda-nos a compreender algumas ideias em torno do ambiente cultural youtubiano.

12 Disponível em:: <http://www.youtube.com/watch?v=W9m9UFhEARg>. Acesso em: 8 fev. 2014.

13 Postado em 17 de novembro de 2009 por @young00era. Disponível em: <http://www.youtube.com/

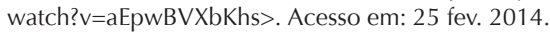


Primeiramente, revelam-nos aspectos do enciclopedismo dos usuários, ou seja a autoconsciência de uma cultura comum constituída por popstars oriundos do Youtube, que contribuíram para a construção de um arquivo de gestos performáticos que fazem parte da história da mediação dessa plataforma. ${ }^{14}$

Em segundo lugar, apontam para a forma como essa história se relaciona a suas próprias vidas ("eu estava na sétima série"; "foi por isto que comecei meu canal de vídeos"), reforçando o argumento de Peter e Seier (2009) em torno da articulação entre experiência subjetiva e recepção midiática tanto quanto entre memória individual e coletiva (HALBWACHS, 1990), que nos remetem a aspectos da mediação dos produtos da cultura midiática na construção da memória cultural. ${ }^{15}$

Em terceiro, aponta para a hierarquia dessa comunidade e suas disputas simbólicas, traduzidas na discussão sobre quem pode opinar sobre os vídeos ("se vc não se lembra deste vídeo é um 'poser'").

Em quarto lugar, os comentários nos permitem testemunhar a atividade de mediação desses usuários em ação, ao participarem da atividade de valoração dos vídeos com comentários que o qualificam como "épico", "lendário", "classic", remetendo-nos ao que Hennion (2002) aponta como a dimensão performativa da valoração baseada no gosto; tanto quanto o caráter coletivo, compartilhado e mediado desse processo.

Negociam, assim, em torno de valores que afirmam o "amadorismo", traduzido em elementos tais como despojamento, simplicidade, espontaneidade, diversão e abertura dialógica para o compartilhamento e apropriações criativas na forma de paródias, corroborando o argumento de Muller (2009) de que a avaliação em torno da qualidade não está ausente das expectativas da audiência de vídeos amadores.

Entre o conjunto de comentários, merece particular destaque o que menciona diversos virais de sucesso da história do Youtube, chegando até Gangnam Style:

The birth of hit YouTube videos. Tron guy, sneezing panda, Friday, chocolate rain, leave Britney alone, dramatic chipmunk, and even the newest ones such as came in like a wrecking ball and Harlem shake trace there roots back to this god amongst men. Only Gangam style really rivals it in popularity. (@Cascadian Ranger, grifo meu)

Assim, ao fazer a ligação entre esse vídeo e o de Psy, esse post nos fornece novos rastros, que vamos explorar na próxima seção a partir do exemplo de Gangnam Style.

\section{Gangnam Style em múltiplas mediações}

O videoclipe Gangnam Style, do gênero pop coreano (k-pop), foi lançado no dia 15 de julho de 2012, e entrou na parada de singles sul-coreana na primeira posição logo

14 Discuti anteriormente este aspecto do letramento dos usuários do Youtube em detalhes. Ver: (PEREIRA DE SÁ, 2014).

15 Para instigante discussão sobre a música como "contêiner da memória", ver De Nora (2000). 
após o lançamento. Cinco meses depois, em 24 de novembro de 2012, chegou a mais de 806 milhões de visualizações, tornando-se o vídeo mais visto da história do Youtube após ultrapassar o vídeo da canção Baby, do cantor pop canadense Justin Bieber. Em seguida, a 21 de dezembro de 2012, tornou-se o primeiro vídeo a ter 1 bilhão de visualizações e permanece na primeira posição, com a incrível marca de 2.016.873.094 visualizações no momento em que escrevo. ${ }^{16}$

Sua sonoridade remete o ouvinte ao gênero pop, dialogando ainda com elementos do gênero disco music; e, exceto pela letra cantada em coreano, poderia seria classificada como uma boa canção dançante do mundo pop anglófono. ${ }^{17}$

Contudo, o videoclipe desmente a primeira impressão. Protagonizado pelo DJ Psy, personagem com traços orientais, vestido em trajes coloridos que se alternam ao longo do clipe e contracenando com uma infinidade de outros atores e cenários tais como um estábulo, uma sauna, um ônibus lotado, uma piscina; e repetindo uma mesma coreografia, apelidada de "dança do cavalo" a partir de sua semelhança com os movimentos de um cowboy - esse conjunto produz um efeito classificado pela revista Rolling Stone ${ }^{18}$ como "espontâneo e ridiculamente engraçado".

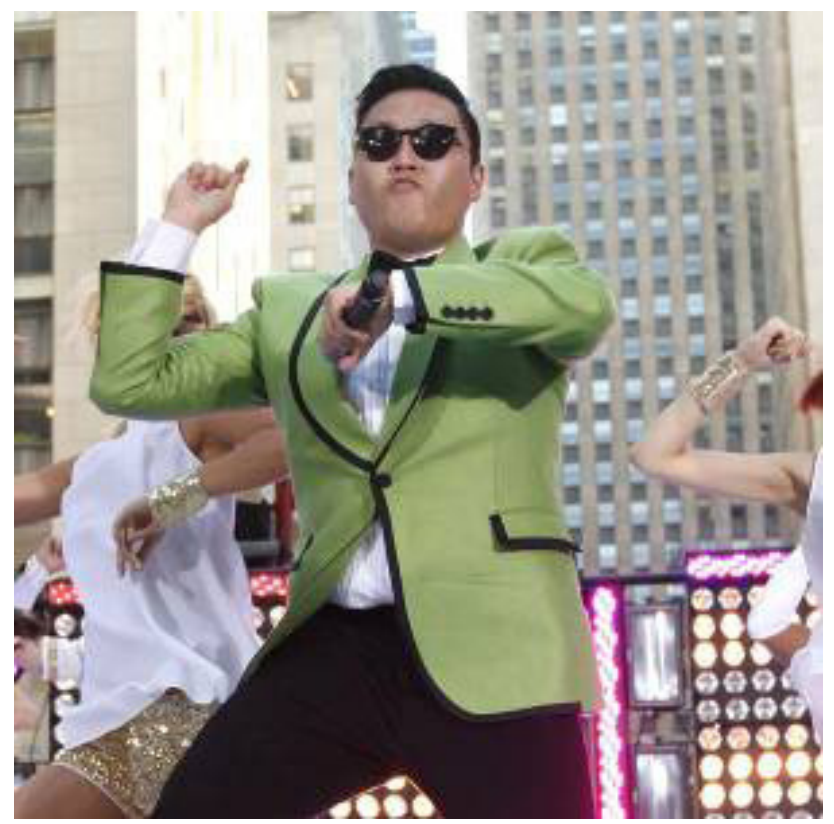

Fig.2. Dj Psy em cena do videoclipe Gangnam Style.

16 Consulta em 16 de junho de 2014.

17 Após o sucesso, vários blogs e publicações especializadas traduziram a letra, explicando que se trata de uma crítica social ao estilo de vida burguês e às mulheres de Gangnam, bairro chique de Seul.

18 Disponível em:: <http://rollingstone.uol.com.br/noticia/destrinchando-o-gangnam-style-de-psy-1/>. Acesso em: 20 fev. 2014. 
Em entrevista à revista, o próprio Psy enfatiza seu esforço em produzir um clipe com situações "cafonas", "ridículas" e "hilárias", explicando:

Quando fizemos essa coreografia, chamamos de "dança do cavalo". Eu disse [ao diretor] "ei, é uma dança do cavalo, então, vamos achar um lugar de cavalo". Dessa forma, pode ser mais cafona. Pode ser mais ridículo. Então, foi o que fizemos. Foi em algum lugar de Seul.

Essa é uma das várias entrevistas que mediam a recepção do videoclipe fora da Coreia do Sul. Assim, Psy explica, na entrevista, quase take por take, detalhes das locações, personagens e cultura sul-coreana.

Sabe aquele programa chamado America's Got Talent? A gente tinha uma versão do reality chamado Korea's Got Talent e o garoto [uma versão miniatura dançante de Psy, na cena] veio de lá. Ele não foi treinado. Ele nasceu assim. Não é incrível?

Sobre a garota ruiva que aparece dançando:

Ela é a líder de um grupo de meninas muito famoso de K-Pop. O nome é 4Minute; o nome dela é Hyun-a. É meio que um símbolo sexual entre os grupos de meninas. Ela super não fazia esse tipo de coisa antes. Ela perguntou: "Por que? Por que? Por que eu fiz isso...?'

Sobre o personagem que dança com ele no elevador, trata-se de um

[...] comediante muito famoso na Coreia. O nome dele é Noh Hong-cheol. É muito meu amigo. Ele foi ao local da gravação só para me incentivar. Era só isso. Não esperava ser gravado. Ele não criou nada. O passo - isso é marca registrada dele. Ele faz isso há muitos anos.

Por sua vez, o "cara de terno amarelo" também é outro comediante conhecido em seus país. "O nome dele é Yoo Jae Suk. No clipe, ele dançou de forma muito séria, não é? Fora do país, ficam assistindo e pensando 'oh, um cara estranho de terno amarelo dançando, quem é ele?' Mas na Coreia, todo mundo pirou: 'Uau, ele está dançando tão sério'".

Outros detalhes do videoclipe também são colocados em contexto, tais como a cena em que idosos viajam no ônibus: "É tipo um ônibus de turnê e muitas das pessoas mais velhas estão viajando para algum lugar nas estradas. Na verdade, acho que isso é ilegal: eles estão de pé". Ou sobre as mulheres andando para trás: "Na Coreia, algumas mulheres idosas andam para trás para perder peso, sabia? Essa é uma situação muito normal na Coreia".

Ao longo de toda a entrevista, a tônica do relato é no improviso e espontaneidade das gravações, buscando extrair das situações o máximo de ridículo, a fim de provocar o humor e a descontração. Ao mesmo tempo, o esforço em traduzir aspectos da cultura 
coreana para uma audiência pouco familiarizada com esse universo também chama a atenção dentre o conjunto de mediações que constroem a relação do vídeo com a sua audiência "global" e que caberia ainda explorar brevemente.

Assim, se voltamos ao comentário citado anteriormente neste trabalho, que traça uma linha evolutiva ligando o videoclipe de Gary Brolsma ao do DJ Psy, encontramos o elo que permite a sugestão de que, para parte dos usuários, esse vídeo se inscreve dentro do conjunto de "vídeos de youtube", traduzido em elementos tais como espontaneidade, humor, improviso e nonsense, associadas a um gesto performático com alto potencial de apropriação, tal como a "dança do cavalo".

Nesse sentido, o letramento da audiência em torno do conjunto de poses e gestos que compõem o imenso arquivo do próprio Youtube, e que povoa a memória de seus usuários, torna-se parte importante do processo de mediação desse vídeo. Além disso, esse arquivo abrange também poses e gestos do pop massivo global e é acionado por Psy ao citar Michael Jackson (logo no início, na cena da neve) e Lady Gaga (na cena da piscina), num processo de intertextualidade característico da cultura do spoof (FELINTO, 2008), e que se torna ainda mais intenso a partir do momento em que somos informados de que vários personagens são muito conhecidos em seu país e reproduzem gestos reconhecíveis para a audiência coreana.

No entanto, se proponho uma linhagem de vídeos musicais que portam traços em comum envolvendo The Numa Numa dance e Gangnam Style, torna-se também necessário reconhecer a "evolução" do segundo vídeo em relação ao primeiro, uma vez que o vídeo de Broslma caracteriza um primeiro momento da estética de automediação, restrito ao ambiente doméstico do quarto e à webcam; enquanto que o segundo remete a um segundo momento dessa estética, marcado pela mediação de mídias móveis tais como os smartphones com câmeras e GPS, que permitem a saída do espaço doméstico em direção à exploração do espaço urbano.

Buscando outras mediações do vídeo de Psy, cabe apontar o conjunto de ferramentas métricas da plataforma que mostram o número de acessos de cada vídeo, em conjunto com o número de likes e dislikes. Assim, o número crescente de acessos provoca um efeito multiplicador, uma vez que outras pessoas se interessam pelo vídeo a partir desse dad. ${ }^{19}$ Somem-se a essas ferramentas as que permitem o compartilhamento com outras redes sociais na própria página do vídeo, multiplicando sua visibilidade; e ainda os comentários, que discutem e repercutem esses números.

Um terceiro tipo de mediação é o dos links de recomendações que o Youtube apresenta ao lado do vídeo. A partir dessa operação, ele é relacionado a vários outros sejam de paródias, covers e apropriações relativamente amadoras; seja vídeos tutoriais,

19 Por exemplo, nesse momento, junho de 2014, quando o vídeo bateu o recorde de 2 bilhões de views, a maioria dos comentários recentes é sobre esse fato, discutido intensamente entre os usuários que deixaram comentários. Acesso em: 16 jun. 2004. 
que traduzem a letra da música para idiomas diversos, ou que decupam os passos da canção didaticamente; seja ainda a outros vídeos do próprio DJ Psy ou outros cantores do k-pop. Desse modo, capturando esse vídeo em diversas redes sociotécnicas que permitem que ele "faça sentido" - múltiplos sentidos, por sinal.

Finalmente, cabe observar que ainda que esse videoclipe tenha ganhado visibilidade, primeiramente através do Youtube, não significa que os mediadores se limitem a essa plataforma. Assim, podemos citar a infinidade de blogs, revistas, críticos e programas de televisão traduzindo e enquadrando o artista para uma audiência ocidental que, em grande parte, o desconhecia até então. Temos aqui mais um exemplo de encadeamento midiático, uma vez que esses mediadores são fundamentais para a repercussão do videoclipe em outras mídias

\section{Considerações finais}

O presente trabalho explorou algumas questões em torno dos elementos expressivos da cultura comum do Youtube e algumas de suas mediações musicais. Para tanto, buscou, entre os vídeos musicais mais vistos através da plataforma, um amador, The Numa Numa Guy, criado e postado por Gary Brolsma, no ano de 2004; e o videoclipe musical profissional mais visto da história do Youtube, Gangnam Style, do DJ sul-coreano Psy, postado em 2012, discutindo suas trajetórias no Youtube a partir de múltiplas mediações e a forma como eles se relacionam a um acervo comum de poses e gestos compartilhado pelos usuários.

Assim, a aposta é a de que o conjunto desses elementos traduz parte dos valores e sensibilidade que Green e Burguess chamam de youtubidade. Elementos que compõem o sistema cultural híbrido da plataforma a partir da ação da rede sociotécnica, formada por amadores, profissionais e suas mídias e artefatos, cujas práticas explorei muito brevemente neste trabalho e que continuam a nos desafiar ao entendimento.

Nessa direção, este paper se encerra com mais perguntas do que respostas. E caberia dar desdobramento à análise aqui iniciada, primeiramente, rastreando uma rede mais complexa de mediadores que deram visibilidade aos vídeos analisados; e que os conectam à midiasfera contemporânea, tais como, por exemplo, os atores institucionais ligados à indústria cultural sul-coreana da qual o DJ Psy faz parte.

Além disso, tomando por base a informação fornecida pela própria plataforma de que $80 \%$ de seu tráfego vem de fora dos EUA, ${ }^{20}$ também caberia explorar aspectos da relação globallocal, entre o pop global de matriz anglo-saxônica e suas inflexões periféricas no contexto de uma audiência globalmente distribuída. Essa discussão, articulada a outras perguntas sobre a composição sociodemográfica detalhada dos usuários que assistem, curtem e comentam os videoclipes e ainda sobre o significado dos números brutos em torno da audiência desses vídeos, também se apresentam como importantes pistas para futuros trabalhos.

20 Disponível em: <https://www.youtube.com/yt/press/pt-BR/statistics.html>. Acesso em: 10 mai. 2014. 
Simone Pereira de Sá é professora do Departamento de Estudos Culturais e Mídia da Universidade Federal Fluminense.

sibonei.sa@gmail.com

\section{Referências}

BURGUESS, J.; GREEN, J. Youtube e a revolução digital. São Paulo: ED Aleph, 2009.

The entrepreneurial Vlogger: Participatory Culture Beyond the Professional-Amateur Divide. In: SNICKARS, P.; VONDERAU, P. The youtube reader. Suécia: National Library of Sweden, 2009a. p. 89-107.

CONTER, M. B. Imagem-Música em vídeos para web. Paródias, reciclagens e remixagens. São Paulo: Kazuá, 2013.

DE NORA, T. Music in everyday life. Cambridge: Cambridge University Press, 2000.

DUNNE, J; MOSER, C. Automedialitát, Subjektconstitution. In: Schrift, Bild and neuen Medien. Munique: Fink, 2008.

FELINTO, E. Videotrash: o youtube e a cultura do spoof na Internet. Galáxia, São Paulo: v. 16, p. 33-42, dez. 2008.

FRITH, S. Performing Rites. On the value of Popular Music. Cambrige: Harvard University Press, 1998.

HALBWACHS, M. A memória coletiva. São Paulo: Ed. Revista dos Tribunais, 1990.

HENNION, A. Music and Mediation: Towards a new Sociology of Music. In: The Cultural Study of Music: A Critical Introduction. CLAYTON, M; HERBERT, T.; MIDDLETON, R. (Org.). London: Routledge, 2002.

HOLZBACH, A.; NERCOLINI; M. Videoclipe em tempos de reconfigurações. Revista FAMECOS (online), v. 1, p. 50-56, 2009.

JENKINS, H. Cultura da Convergência. São Paulo: Aleph, 2008.

KEEN, A. O Culto do Amador. São Paulo: Zahar, 2009.

LATOUR, B. Reassembling the Social: An Introduction to Actor-Network-Theory. Oxford: Oxford Univ. Press, 2005.

MULLER, E. Where Quality Matters: Discourses on the Art of Making a YouTube Video. In: SNICKARS, P.; VONDERAU, P. The youtube reader. Suécia: National Library of Sweden, 2009. p. 126-139.

PEREIRA DE SÁ, S. - Apropriações low-tech no funk carioca: a Batalha do Passinho e a rede de música popular de periferia. Revista Fronteiras (Online), v. 16, p. 28-37, 2014.

PEREIRA DE SÁ, S.; Holzbach, A. \#u2youtube e a performance mediada por computador. Galáxia (São Paulo. Online), v. 10, p. 146-160, 2010.

PETERS, K.; SEIER, A. Home dance: Mediacy and Aesthetics of the self on youtube. In: SNICKARS, P.; VONDERAU, P. The youtube reader. Suécia: National Library of Sweden, 2009, p. 187-203.

SNICKARS, P.; VONDERAU, P. The youtube reader. Suécia: National Library of Sweden, 2009 
SOARES, T. Videoclipe, youtube e televisão expandida. Notas sobre Itinerários do audiovisual na cultura midiática. In: INTERCOM, 32, Curitiba. Anais... Curitiba, 2009.

STRANGELOVE, M. Watching youtube: extraordinary videos by ordinary people. Toronto: University of Toronto Press, 2010.

VERNALLIS, C. Unruly media: youtube, Music Videos and the new digital cinema. Oxford: Oxford University Press, 2013.

WILLIAMS, R. Television: technology and cultural form. London: Routledge, 1990.

ZILLER, J. Expressões antropofágicas: apropriação e recriação de vídeos no YouTube. Revista Contemporânea, Salvador, UFBA, v. 10, n. 3, p. 741-758, set-dez, 2012.

Artigo recebido em junho e aprovado em agosto de 2014. 